\title{
Islamic State Enters Al-Qaeda's Old Hotbed: Afghanistan and Pakistan
}

\section{Mona Kanwal Sheikh}

Danish Institute for International Studies, http://www.diis.dk

\begin{abstract}
The Islamic State (IS) movement has opened a new chapter in the Afpak region, changing the landscape of militant movements in the area. This article looks at the patterns of rivalry and collaboration between the Islamic State on one side and Al-Qaeda and Taliban-related movements on the other. It also surveys the way Al-Qaeda has developed during the past years where most of the international attention has been devoted to the formation of IS in Iraq/Syria, and shows that Al-Qaeda is still active, though it has become more locally oriented. Finally, the article looks at the prospects for the further expansion of IS especially in Pakistan where, on one side, a range of sectarian anti-Shia movements that resonate with parts of the IS agenda while, on the other side, there is no ideological tradition for embracing the kind of caliphate-jihadism that the IS advocates.
\end{abstract}

Keywords: Jihadism, Islamic State Khorasan, Al-Qaeda, Taliban, Afghanistan, Pakistan, terrorism.

\section{Introduction}

Ten years ago, the borderlands between Pakistan and Afghanistan were the command post for leaders of Al-Qaeda (AQ). But what has happened with $A Q$ since then? And what sort of collaboration or conflict is there between the dominant Taliban-related movement in the region, $A Q$, and the new kid in town - Islamic State (IS)? Below I look at the emergence of IS in Afghanistan and Pakistan and the dynamics that have impacted the relationship between the "old" movements in the region (Taliban and AQ) on the one hand, and IS on the other. IS is still a fledgling movement in the "afpak" region, and therefore there is still no clear picture of its influence and resonance in Afghanistan and 
Pakistan. Because the situation is still unfolding, this article is based on very limited source material about the movement. ${ }^{1}$

\section{Islamic State Khorasan}

In early 2015, the Islamic State movement opened a new chapter, operating in Afghanistan and Pakistan. The establishment of the new Afghan-Pakistani fraction of IS was announced by a central spokesman, Abu Muhammad Al-Adnani, from one of IS's headquarters in Syria. In an almost seven-minute-long speech, Al-Adnani announced that the group would be expanding to what he called "Khorasan." Hence this fraction is referred to below as "ISK" (Islamic State Khorasan). The speech was published on 26 January 2015 in Al-Furqan, the IS media bureau. The announcement came a few weeks after a group of former Taliban supporters in Pakistan set up a so-called "Khorasan Council" (shura) and publicly declared their loyalty to IS.

The Afghan-Pakistani fraction is therefore closely linked to the IS movement that emerged in Iraq during 2013. The leadership of ISK has declared its loyalty (bayah) to Abu Bakr Al-Baghdadi, the self-appointed caliph, who surprised the world when he spoke about his mission at a mosque in Mosul in July 2014. While ISK has only a limited presence in Pakistan, today it is present in around seven Afghan provinces, primarily in the eastern part of the Kunar province and the adjacent Nangarhar province. The ISK has challenged the afghan Taliban in both Nangarhar, Herat, and Helmand, but Eastern Nangarhar has emerged as the strongest base of IS presence in Afghanistan ${ }^{3}$ (Fig. 1).

The movement has made its presence felt by taking responsibility for suicide attacks, armed operations and kidnappings, particularly in south-eastern Afghanistan, where ISK has unsuccessfully tried to occupy certain areas, but also in north-eastern Afghanistan, where the movement has been more successful. The ISK has also attacked Pakistani interests in Afghanistan, including a

1 The existing literature on IS mostly looks at IS' emergence in Iraq and its extension into Syria. There is a substantial amount of policy papers and reports on the subject (including publications by Brookings, Carnegie, International Crisis Group and DIIS). Books dealing with the rise of IS include e.g. Jessica Stern and J.M. Berger, ISIS: The State of Terror (New York: HarperCollins, 2015); Charles R. Lister, The Islamic State: A Brief Introduction (Washington, D.C.: Brookings, 2015); Patrick Cockburn, The Rise of Islamic State: ISIS and the New Sunni Revolution (London: Verso, 2015); Abdel Bari Atwan, Islamic State - the Digital Caliphate (London: Saqi Books, 2015); William McCants, The ISIS Apocalypse: The History, Strategy, and Doomsday Vision of the Islamic State (Washington, D.C.: Brookings, 2015).

2 The declaration, published on January 26, 1014 by Al-Furqan, the media agency of Islamic State, came only a few weeks after a group of former TTP representatives established a shura and declared allegiance to Al-Baghdadi.

3 Vanda Felbab-Brown, Blood and Faith in Afghanistan (Washington, D.C.: Brookings, 2016), available at www.brookings.edu/research/blood-and-faith-in-afghanistan-ajune-2016-update. 


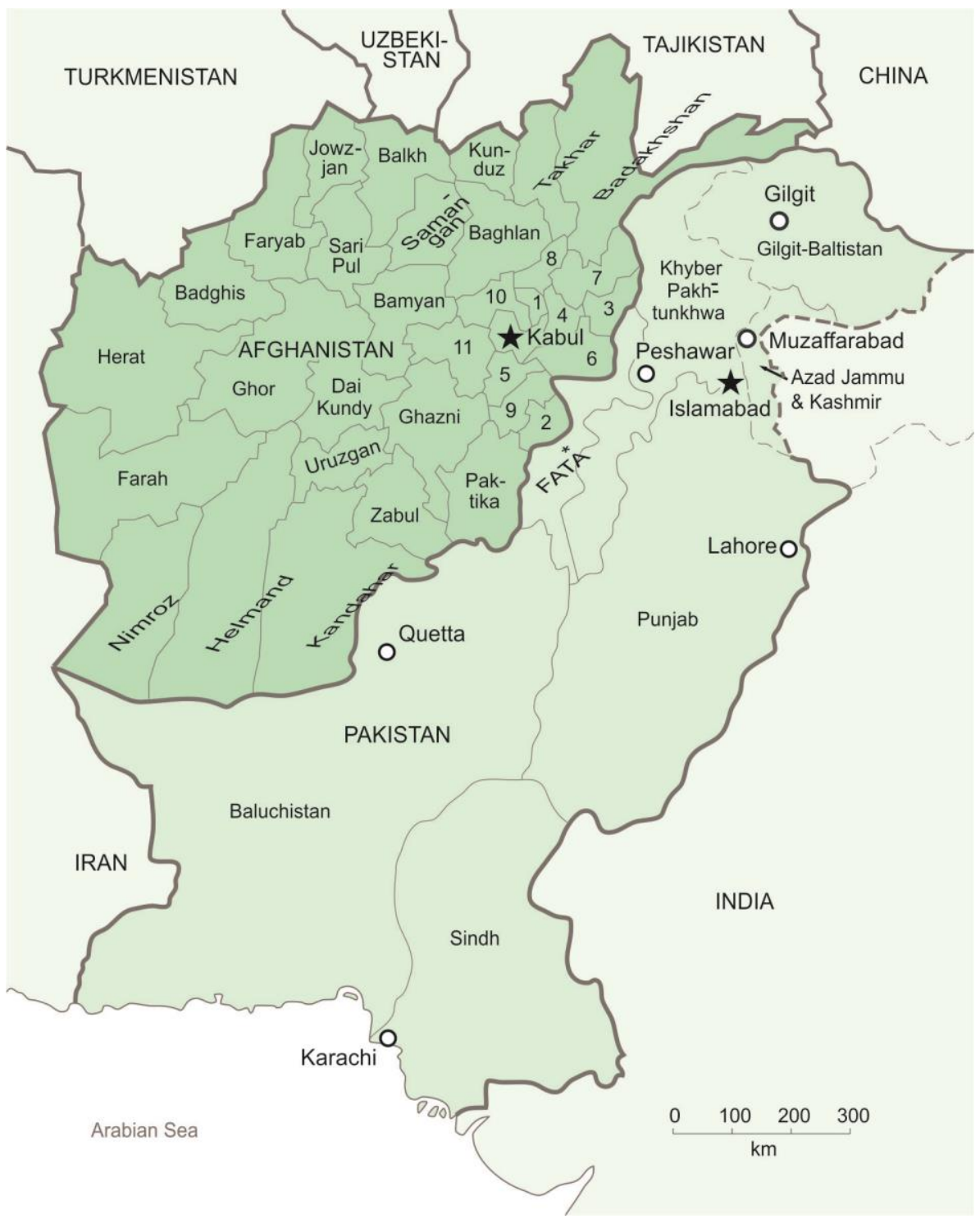

Figure 1: Map of Afghanistan and Pakistan.

Pakistani consulate in Jalalabad, the capital of Nangarhar. ISK has also been active in Pakistan, particularly with attacks in the Sindh province, and according to Pakistani news coverage, ISK has managed to gain supporters in the tribal areas of Pakistan (FATA), where the Pakistani Taliban still has its strongholds and where Al-Qaeda previously enjoyed widespread popularity and protection. 
The new IS fraction is called ISIL-K (Islamic State of Iraq and the Levant Khorasan) on the US list of terrorists, ${ }^{4}$ while it refers to itself as Wilayat Khorasan. Wilayat is a term referring to the independent administrative units existing under the historical caliphate system and therefore the name is sometimes translated to the "Khorasan province." The Afghan-Pakistani fraction therefore considers itself as an administrative and military unit of the global Islamic caliphate, which became the ambition of the IS movement in 2013 when it expanded its activities in Iraq to include Syria.

According to reports from the United States Military Academy at West Point, the Afghan-Pakistani fraction of the movement was already under way in early 2014, ${ }^{5}$ when former Al-Qaeda supporters in Afghanistan and Pakistan adhered to the notion that the Iraqi, Abu Bakr Al-Baghdadi was the caliph, who will unite the Muslim world before the final apocalypse unfolds.

Note that, despite being called a "province," Khorasan is not a territorial area. It makes more sense to consider it as a movement in Afghanistan and $\mathrm{Pa}$ kistan that is endeavoring to realize the IS vision of an Islamic caliphate. Khorasan does not exist as a province any more, but it refers to an historical region covering parts of Afghanistan, Turkmenistan, Tajikistan, Uzbekistan and much of Iran. Some descriptions of the historical area also include parts on Pakistan. Legend has it that Khorasan also existed as a pivotal element in eschatological narratives of the final days leading up to the day of judgement. For example, a hadith [a report attributable to the words, actions or habits of the prophet Muhammad] that has been used to establish legitimacy for the IS movement, predicts that an army will rise up in the Khorasan area bearing a black banner. The Muslim messiah (known as imam Mehdi in the eschatology) will come forward from this army and lead the Muslims to final victory against the enemies of Islam, thus re-establishing the glory of Islam. An element in this hadith calls upon all Muslims to join the "army of the black banner" when it appears. The legend of Khorasan as an area in which decisive events will occur can also be found among Taliban supporters, although they do not recognize IS as the movement that will lead Islam to final victory.

ISK's strongholds in Afghanistan are in the Kunar province in north-eastern Afghanistan and in the adjacent Nangarhar province (especially in the Achin district). Both these areas border with the tribal areas in Pakistan (FATA - Federally Administered Tribal Areas, Fig. 1). ISK is reported to have attempted to occupy the southern Farah, Helmand and Zabul provinces, although without

4 Bureau of Public Affairs Department of State. The Office of Website Management, "Designations of Foreign Terrorist Fighters," Press Release| Media Note, U.S. Department of State, September 29, 2015, available at www.state.gov/r/pa/prs/ps/2015/ 09/247433.htm.

5 Don Rassler, "Situating the Emergence of the Islamic State of Khorasan," CTC Sentinel 8, no. 3 (March 2015): 7-11, available at https://www.ctc.usma.edu/posts/situatingthe-emergence-of-the-islamic-state-of-khorasan. 
success. ${ }^{6}$ The ISK warriors comprise Afghans, Pakistanis and Uzbeks from the IMU (Islamic Movement of Uzbekistan), who have previously cooperated with Al-Qaeda and the Taliban. A 2015 UN report described how ISK took over parts of the Nangarhar province by forcing 25 schools to close and by threatening teachers and parents (the schools were allegedly taken over to organize their military activities).

ISK is still so new that it is hard to say anything firm about the nature and structure of the movement. However, reports from journalists and news stories give some insight into the movement that is often perceived as AQ's "superior" with regard to their methods and dramatic use of violence.

\section{IS move into Pakistan}

During 2015, it became clear that ISK was slowly encroaching on the Pakistani "jihad arena," partly because leading members of various Pakistani militant movements announced their allegiance to IS and Al-Baghdadi and because IS propaganda has been found in Pakistan. There have been reports about IS flags and pro-IS graffiti on walls in Karachi and Peshawar - both cities that were previously strongholds for Al-Qaeda sympathizers and supporters of the Taliban. In late 2015, there were also reports of IS propaganda videos being distributed in Afghanistan and Pakistan, and reports of a radio station being established called "The Voice of the Caliphate" (with programs in Arabic, Pashto, Farsi and Dari), although this was quickly closed down after US air strikes on the station's studio. ${ }^{7}$

In May 2015, a lethal attack on 46 Shia Muslims was linked to an IS-related movement in Karachi, which is located in the Sindh province. Jundullah-a group which had pledged allegiance to IS in November 2014-claimed responsibility for the clearly sectarian attack. Jundullah has previously been associated with the Pakistani fraction of the Taliban, but ideologically it is closer to IS and its mission to re-establish a transnational Islamic caliphate.

Again in 2015, 42 people were arrested in Sialkot (in the Punjab province) because they were allegedly part of an IS cell. In the Pakistani capital of Islamabad, a suspected Pakistani IS leader was arrested and accused of recruiting for the movement. The Pakistani media reported that the arrest also revealed that IS paid new recruits a monthly wage of USD 380 for joining the IS cause. ${ }^{8}$ This amount has been reported as higher by other sources, but nevertheless, the wage has contributed to expanding IS' presence in Pakistan, especially in the

6 Franz J. Marty, "On the Trail of the Islamic State in Afghanistan," Foreign Policy, April 5, 2016, https://foreignpolicy.com/2016/04/05/afghanistan-islamic-state-taliban/.

7 Ibid.

8 Farhan Zahid, "Growing Evidence of Islamic State in Pakistan," Terrorism Monitor 14, no. 3 (February 2016): 3-5, available at www.jamestown.org/programs/tm/single/ ?tx_ttnews\%5Btt_news\%5D=45065\&cHash=547a6e0e90327659248b7108b3925ab0. 
tribal areas, where thousands of young men and women live in harsh circumstances with unemployment and poor socio-economic conditions. ${ }^{9}$

The IS English-language magazine, Dabiq, recently brought an interview with "the governor (wali) of Khorasan," where he says that Khorasan now comprises Afghanistan and western Pakistan, and that IS has ambitions to move into Kashmir (an area of contention between Pakistan and India). With regard to their foothold in the region, he says, "We have established judicial courts in these regions, offices for hisbah [a sort of religious police force], offices for zakah [charity/alms], and others for education, da'wah [proselytizing] and masajid [mosques], and public services. ${ }^{10}$ However, the activities he refers to are more about Afghanistan than Pakistan, from where there are only sketchy reports on the establishment of IS-related sharia courts or other types of parallel administration.

The umbrella organization for the Taliban in Pakistan, Tehrike Taliban Pakistan (TTP), is composed of whole movements that have joined the TTP, as well as smaller splinter groups from other movements, and ISK in Pakistan follows a similar pattern. As mentioned above, one of the movements that have publicly declared its allegiance to ISK is the anti-Shiite Jundullah movement. The Jundullah movement agrees with IS' choleric portrait of Shia Muslims as "deniers" (rafidah), and claims that Shia Muslims do not recognize the Prophet's successors, Abu Bakr and Umar, as legitimate caliphs, arguing that they are not merely defectors but a serious ideological threat to the true Islam and must be vanquished. Jundullah started as a movement of exiled Sunni Muslim Iranians who wanted to overthrow the Shia Muslim regime in Iran, and over time it has become more focused on combatting the "defectors" in Pakistan.

As mentioned above, another movement that has allied itself with ISK is the Islamic Movement of Uzbekistan (IMU). ${ }^{11}$ The IMU has been struggling to establish an Islamic state in Uzbekistan for many years from its exile in Pakistan and Afghanistan, and it has previously collaborated with AQ. It is likely that IS considers an alliance with the militant IMU as extremely valuable as, at least on paper, IS has ambitions to take over the historical Khorasan (much of which is in Central Asia) and thereby fulfil the prophecy in the hadith that is referred to in their propaganda and by the movements that have joined their struggle. In November 2015, however, the IMU was weakened by a clash with the Afghan Taliban and was further fragmented when, in June 2016, a small IMU group questioned the former leader's loyalty to IS and instead declared loyalty to AlQaeda. Preliminary reports indicate that the ISK movement has also attracted warriors who previously fought for more locally based Pakistani movements such as Sipahe Sihaba and Lashkare Jhangvi. Both these groups are well known

9 Marty, "On the Trail of the Islamic State in Afghanistan."

"Interview with the Wali of Khurasan," Dabiq 13, pp. 48-58, quote on p. 49.

11 Merhat Sharipzhan, "IMU Declares It Is Now Part of the Islamic State," Radio Free Europe/Radio Liberty, August 6, 2015, http://www.rferl.org/content/imu-islamicstate/27174567.html. 
for their anti-Shia sentiments and over the years they have been behind many militant attacks on Shia Muslims in different parts of Pakistan. In some cases, ISK warriors have a dual loyalty, meaning that they do not necessarily definitively leave the movement from which they came, but just join the cause for which they have most sympathy at any particular time.

Other movements that have seen a transfer of members to ISK include Lashkar-e-Taiba (LeT), Tanzime Nifaze Shariate Muhammadi (TNSM), and the TTP. Despite this "defection" of members, the three movements are still intact and working to realize their own goals. Cooperation between parts of LeT and ISK is particularly based on personal relationships between IS leaders and LeT leaders in the tribal areas of Pakistan. There can be strategic and amicable reasons for temporary cooperation, that movements protect each other, or that they provide logistical assistance for each other, but complete absorption of LeT in ISK is hard to imagine, as LeT's primary struggle has always been for Kashmir and directed towards their arch enemy: India. Since TTP was established in 2007, however, LeT has split and a small fraction has joined the TTP cause in the tribal areas in Pakistan, thereby turning their backs on the previous ties of loyalty to the Pakistani army. However, note that the LeT movement has never been driven by a vision to establish an Islamic caliphate, but in addition to its militant activities, it is a missionary movement to spread the teaching of Islam through what it considers as correct Islamic education and upbringing. In other words it believes in Islamization from the bottom up and, in contrast to other Islamic movements in Pakistan, it has never had a strong voice in discourses on the establishment of an Islamic state in Pakistan. Furthermore, LeT has an arch-nationalistic ethos (identified in its opposition to the Indian identity), and its fight has been for the border between India and Pakistan, which is hard to align with IS' transnational caliphate project.

On the other hand, TNSM was established to Islamize the Pakistani state. Since 2007 it has primarily been associated with the Taliban, but even though it has fought for an Islamic state as a national project, the idea of an Islamic caliphate is not entirely remote for TNSM and it is not unthinkable that parts of the movement could be attracted by the IS idea that we are approaching the apocalypse. As a movement, TNSM has not yet pledged loyalty to Al-Baghdadi and primarily just individuals from the movement have joined ISK.

The former supporters of TTP who have joined ISK have done so because they were dissatisfied with the way the Taliban in Pakistan was developing. Some say that this reflects the leadership crisis that hit the Taliban when the TTP leader, Hakimullah Mehsud, was killed by the Americans in 2013. The critical TTP supporters, especially the original supporters based in the tribal areas, were never satisfied with the appointment of Mullah Fazlullah (who has no ties with the tribal areas) as the successor to Hakimullah Mehsud, who was not just the head of the Taliban in Pakistan but also a powerful tribal leader. The former members of TTP who have joined ISK have therefore lacked a leader in whom they have confidence. Moreover, the Taliban has been divided on the issue of 
whether to enter into peace agreements with the Pakistani state, or whether such action would be a symbolic pact with an infidel system. Fragmentation of the Pakistani Taliban movement has also meant that some of the warriors in the movement have become disillusioned with the movement's lack of potency and it is very likely that as a result they have seen IS as a strong alternative.

\section{Is there room for IS?}

The relationship between TTP in Pakistan and the Taliban in Afghanistan on the one hand, and IS on the other, has primarily been characterized by tension and internal power struggles, rather than cooperation and integration. In other words, as things stand now, IS and the Taliban cannot be considered as united or uniting, but more as competing movements that weaken each other by fighting against each other.

News of the death of Mullah Omar spread in the summer if 2015. Mullah Omar was a uniting force for both the Pakistani and Afghan Taliban who had sworn allegiance to him. Although, like Mullah Omar, Al-Baghdadi also went by the title "Amir ul Momineen" (leader of the faithful), Mullah Omar never claimed the status of caliph, reflecting that the Taliban remained a national project. Supporters of the Taliban movement therefore do not automatically recognize Al-Baghdadi or the legitimacy of the transnational caliphate project, and in many cases there have been statements in which the Taliban belittle the need for a movement like the IS. The main objective of the Taliban in Afghanistan today is to re-establish the emirate as it was in Afghanistan under the rule of Mullah Omar from 1996 to 2001. In Pakistan, the Taliban want to realize the vision they believe was behind the very foundation of Pakistan in 1947: the vision of an Islamic national state for Muslims in what was then India.

According to reports, there is currently open conflict between the Taliban and ISK, particularly in eastern Afghanistan. A recent Al-Jazeera documentaryISIL and the Taliban-portrays the dynamics now impacting the relationship between the Taliban and ISK. ${ }^{12}$ In one scene, for example, ten men are executed by ISK because they have cooperated with the Taliban. The documentary also shows how the Taliban in Afghanistan sees no need for a movement such as IS and how IS describes the Taliban as being in the pockets of Pakistani intelligence services and therefore not fighting an authentic struggle for Islam. The animosity between ISK and the Taliban is also evident in the propaganda issued by IS. In one interview, the governor of Khorasan describes the Taliban as a nationalistic movement that is not just in the pockets of the Pakistani intelligence, but which is also inspired by tribal tradition rather than the laws of God. ${ }^{13}$

12 Jamie Doran and Najibullah Quraishi, "ISIL and the Taliban," Al-Jazeera, November 1, 2015, http://www.aljazeera.com/programmes/specialseries/2015/11/islamic-stateisil-taliban-afghanistan-151101074041755.html.

13 “Interview with the Wali of Khurasan," p. 49. 
The leadership of ISK is composed of defectors, i.e. former Taliban leaders (although not from the highest echelons in the hierarchy). In simple terms these are those who were dissatisfied with the overall leadership of the Pakistani Taliban and therefore decided to break away. Hence, they have a personal agenda in their actions against their previous fellow warriors. However, the Taliban movements remain much stronger than ISK, and preliminary observations estimate that approximately 1,000 men are linked to the ISK movement (mostly concentrated in Nangahar in Afghanistan and the tribal areas in Pakistan). ${ }^{14}$ ISK is therefore not a strong player right now, but this can certainly change if more local movements join the black banners.

Looking at the Taliban movements in Afghanistan and Pakistan, neither of them have broken with the culture in which they have been entrenched and from which they have arisen. On the contrary, they have taken over some of the social structures in which leadership and loyalty depend on family and tribal bonds as well as the ability of the leader to provide safety and security for his foot soldiers and their families. For the same reason, the relationship between a foreign movement like IMU and the Taliban has never been very close, and it is very likely that cultural differences are too great between a movement like IS, with its transnational ethos, and the Taliban with its traditional society and tribal-specific hierarchies, and where personal relationships with the leaders are important.

There are significant internal differences and conflicts between the Taliban (both the Afghan and Pakistani) on the one hand, and ISK on the other, with ISK's strength being challenged in power struggles with the rivalling movements. Furthermore, IS comes with a new ideology that has not really received any support in Pakistan and Afghanistan before. The challenge facing ISK is firstly to get the existing militant movements to recognize Al-Baghdadi as the caliph and messiah figure and, secondly, to convince the existing movements that it is apocalypse now and that IS is the army with the black banner described in the mythological prophesies.

\section{What about Al-Qaeda?}

The relationship between ISK and Al-Qaeda in Afghanistan and Pakistan is just as tense as that between ISK and the Taliban. This can be seen in IS propaganda, where Al-Qaeda in Pakistan is portrayed as an extension of Pakistani intelligence in the same way as the Taliban. ${ }^{15}$ It is interesting to note that the leadership of Al-Qaeda has been loyal to the spiritual leader of the Taliban since 2001. Osama bin Laden maintained the loyalty (bayah) he had sworn for

\footnotetext{
14 Bill Roggio, "State Department Lists Islamic State's 'Khorasan Province' as Foreign Terrorist Organization," The Long War Journal, January 14, 2016, available at http://www.longwarjournal.org/archives/2016/01/state-department-lists-islamicstates-khorasan-province-as-foreign-terrorist-organization.php.

15 "Interview with the Wali of Khurasan," p. 49.
} 
Mullah Omar, and the AQ leader, Ayman al Zawahiri, reaffirmed that loyalty after the death of Osama bin Laden. When the death of Mullah Omar was announced, Al-Zawahiri swore loyalty to the successor, Mullah Mansour. Recently, after Mullah Mansour had been killed by the Americans, the regional chapters of $A Q$, i.e. AQAP, AQIM and the Al Nusrah Front issued a joint statement extolling the deceased Emir, and Zawahiri has subsequently pledged loyalty to the new leader of the Taliban, Hibatullah Akhundzada. Neither the Taliban nor Al-Qaeda have ever recognized Al-Baghdadi as a legitimate caliph; on the contrary they have issued several statements in which they confirm that their loyalty still remains with their own causes.

The original headquarters of Al-Qaeda were in Afghanistan and Pakistan, and in the years following 2001 the international community concentrated on striking at the organization known at that time as Al-Qaeda Central (AQC). AQC referred to the central leadership and the counselling body (shura) in which the central decisions of the organization were made. The original core of Al-Qaeda is now significantly reduced and several observers have indicated that the original AQC and shura do not have the same power as before, and the movement is much more decentralized than at the start. ${ }^{16}$ However, Al-Qaeda never left the region, even though falling media interest in Al-Qaeda and Afghanistan/Pakistan could leave this impression.

There is some debate as to the strength of Al-Qaeda in Afghanistan today. In October 2015, the US attacked an Al-Qaeda encampment in Kandahar, and this sowed some doubt on the number of Al-Qaeda warriors American intelligence had previously said were left in Afghanistan (estimates ranged between 50-100 men). ${ }^{17}$ There turned out to be more than 150 active $A Q$ warriors in the camp in Kandahar alone. ${ }^{18}$ Moreover, 338 attacks on Al-Qaeda have been recorded in 25 out of the 34 provinces in Afghanistan between 2007 and 2013, and this has provoked critical voices to question the official figures from the US authorities. ${ }^{19}$ However, it remains difficult to put a concrete figure on the strength of Al-Qaeda, as a number of movements periodically cooperate with Al-Qaeda, and whether these should be included depends on the breadth of the definition of $A Q$.

16 Deb Riechmann, "Al-Qaida decentralized, but not necessarily weaker," Associated Press, June 1, 2014, available at http://bigstory.ap.org/article/al-qaida-has-changedshape-it-weaker.

17 Eric Schmitt and David E. Sanger, "As U.S. Focuses on ISIS and the Taliban, AI Qaeda Reemerges," NY Times, December 29, 2015, available at www.nytimes.com/2015/ 12/30/us/politics/as-us-focuses-on-isis-and-the-taliban-al-qaeda-re-emerges.html.

18 Thomas Joscelyn and Bill Roggio, "US Military Admits Al-Qaeda is Stronger in Afghanistan than Previously Estimated," The Long War Journal. April 13, 2016, available at http://www.longwarjournal.org/archives/2016/04/us-military-admits-alqaeda-is-stronger-in-afghanistan-than-previously-estimated.php. Ibid. 
A new branch of Al-Qaeda was set up in Pakistan in September 2014 - AlQaeda on the Indian Subcontinent Al-Qaeda Bar-i-Sagheer (AQIS). Ayman AlZawahiri announced the existence of AQIS, which was to operate in Pakistan, India, Bangladesh and Myanmar. An AQIS spokesman later highlighted that the main objectives of AQIS are to combat the American presence, establish Islamic law in South Asia, bring an end to the occupation of Muslim countries, and defend an Afghanistan under the now deceased Mullah Omar. When the Pakistani army initiated military operations in northern Waziristan in the tribal areas of Pakistan, it seems that parts of AQIS moved to southern Afghanistan (Kandahar and Helmand), where they took control of some areas with the Taliban.

What is interesting about AQIS is that it is a regional movement (like AQAP and AQIM) that aims more at a local influence and to recruit locally. AQ has previously had a clearly Arabic ethos (with primarily Egyptians, Saudis, Yemenites and warriors from Libya), and in recent years it has been more open to local movements. Even though some analysts have indicated that the establishment of AQIS was primarily a response to the influence of ISK in the region, the movement also expresses an institutionalization of a development that had already taken place. For example, as long ago as 1992 it was known that AlQaeda was active with regard to Muslims in Myanmar who had been displaced by militant monks. The Mahaz-e Islami movement in particular has had ties to $A Q$ going back several years, and it has groups of supporters in Myanmar, Pakistan and Afghanistan.

So far, the group has not organized many serious attacks, but it came into the spotlight when it took responsibility for an attack on Pakistani ships in Karachi, after which the group issued a statement that the attack was because American and Indian forces had infiltrated the Pakistani fleet and the attack was on the Americans and Indians, and not on Pakistan. Since then, several AQIS leaders have been hit in drone attacks.

\section{Caliphate-Jihadism}

The Taliban in Pakistan primarily appeared as a reaction to military operations by the Pakistani army in the tribal areas and in the capital, Islamabad, where the Red Mosque was attacked by the army in 2007 after being linked to terrorism. As time passed, the Pakistani Taliban allied itself with the voices that, in a Pakistani context, had advocated that Pakistan should be an Islamic state (rather than merely a state for Muslims). Neither Pakistan nor Afghanistan have had strong groups advocating the establishment of a transnational Islamic caliphate across borders. On the contrary, both the original Afghan Taliban and the Pakistani Taliban (and most of the other militia fighting in Afghanistan and Pakistan) have been strongly nationalistic movements, fighting for the "real Afghanistan" and the "real Pakistan," i.e. they have been fighting to define the states' identity, law and administration.

ISK represents a transnational project that can be hard for local movements to embrace. However, the next couple of years will show whether ISK is able to 
spread its ideological vision. Any success they have will depend in part on how polarized the war against the West becomes over the next few years. With greater military engagement against IS in Iraq and Syria (and a renewed risk that the military engagement returns to Afghanistan if ISK gets a firm foothold), there is a risk that the apocalypse could become a self-fulfilling prophesy and it will become easier to convince potential recruits that the Muslim world must unite against the "common enemy."

Apart from the transnational project itself, the distinctive ideology of IS compared with the existing movements that have embraced jihad in Pakistan and Afghanistan is the ambition for a caliphate with violent jihad. Although AlQaeda's propaganda does refer to the caliphate, and presents it as a desirable idea, establishment of a caliphate has never been the primary driving force for Al-Qaeda and it was only a marginal element in statements by Osama bin Laden and his successors. Neither has the notion of breathing new life into the caliphate been particularly popular among the militant organizations in Afghanistan and Pakistan. In fact, the idea of a caliphate has been a marginalized view, born, in addition to Al-Qaeda, by the minor Hizb ut Tahrir movement in Pakistan, although this group has not encouraged violent jihad to achieve its goals.

The expansionist and violent caliphate-jihadism is therefore a new project that will require some time to incubate in the area. Furthermore, IS operates with the idea that it is fighting an offensive jihad that according to most of the militant movements in the region this can only be considered legitimate under a Muslim leader/commander. Even a movement such as the Taliban in Pakistan has only declared its jihad as defensive, as it lacks a Muslim leader who, according to general militant interpretations of jihad, will make it legitimate to lead an offensive-expansive war. Therefore, support for the offensive jihad requires that Al-Baghdadi is recognized as a caliph.

Since the Taliban is the most dominant military movement in both Afghanistan and Pakistan, the doctrinal difference is also significant with regard to whether or not it is conceivable that the two movements can join to form a united front. While IS finds its thoughts and ideas from established Salafi authorities like Ibn Taymiyya, and has been inspired by the earlier Wahhabist tradition (before this merged with Saudi royalism) and one of the main Islamist ideologues, Sayyid Qutb, IS' religious authorities are also present among new generations of younger ideologists (e.g. the 30-year-old Turki Al-Bin'ali), who combine Wahhabism with the caliphate idea and violent jihad. ${ }^{20}$ The irony is that, although IS now legitimizes re-establishment of the caliphate, part of the motivation for the movement comes from a Wahhabism that historically started as caliphate-critical.

What these ideological and theological characteristics come to mean, and how successful ISK is in convincing the militant movements in the region to

${ }^{20}$ Cole Bunzel, From Paper State to Caliphate: The Ideology of the Islamic State (Washington, D.C.: Center for Middle East Policy at Brookings, March 2015), available at http://www.brookings.edu/research/papers/2015/03/ideology-of-islamic-state. 
swear loyalty to Al-Baghdadi, ally themselves with caliphate-jihadism and strike the final blow against the infidel, will become apparent over the next couple of years. If the movement cannot convince the militant movements that are active in the region, then they will continue an internal war to suppress their opponents, as is now reflected in the conflict between the Taliban and IS.

\section{About the author}

Mona Kanwal Sheikh, PhD, is a Senior Researcher in the field of International Security at the Danish Institute for International Studies. Her main area of expertise is militant movements in Pakistan, especially the movements related to the Pakistani Taliban. Her research focuses on religious justifications of, and mobilization to, violence. She has also worked more broadly with Islamist ideologies related to Al-Qaeda, Hamas and the Muslim Brotherhood. 